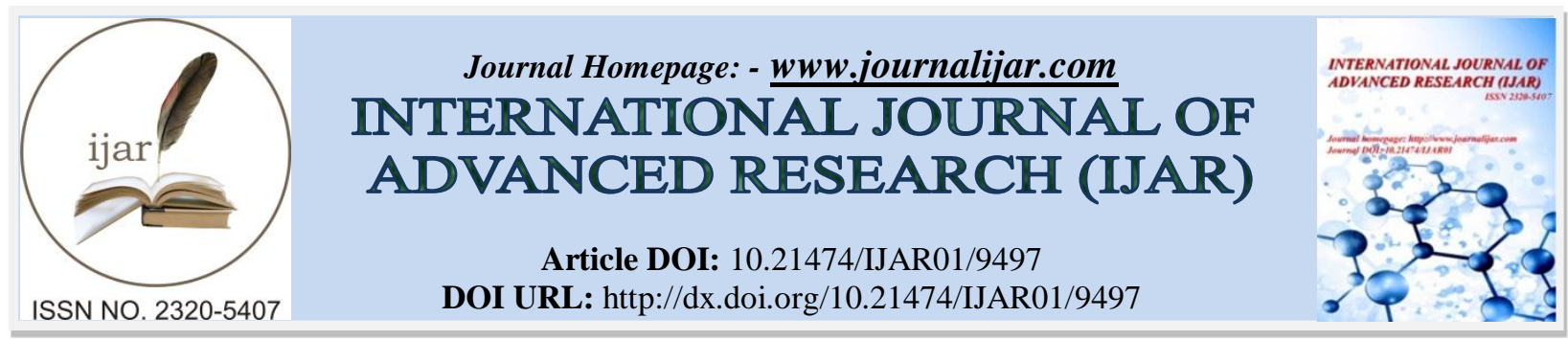

RESEARCH ARTICLE

\title{
COMPUTER LITERACY AND JOB PERFORMANCE OF GOVERNMENT EMPLOYEES AND OFFICIALS IN THE MUNICIPALITY OF CALINOG.
}

\author{
Rose May Cora P. Lagon, Ed.D. \\ Associate Professor V, School of Information and Communications Technology, West Visayas State University \\ Calinog Campus, Calinog, Iloilo, Philippines 5040.
}

\section{Manuscript Info}

Manuscript History

Received: 05 June 2019

Final Accepted: 07 July 2019

Published: August 2019

Key words:-

Computer Literacy, Job Performance,

Government Employees and Officials,

Municipality of Calinog.

\begin{abstract}
This study determined the computer literacy and job performance of government employees and officials in the Municipality of Calinog, Calinog, Iloilo, Philippines as practice by the respondents. Descriptive type of research was utilized in the study. Results showed that respondents are skilled in computer operations skills, set up maintenance and troubleshooting, word processing, introductory desktop publishing, spreadsheet/graphing, databases networking, telecommunications but moderately skilled in media communication. They are average and high in different aspects of job performance. It means that in these aspects, there are still areas for improvement.
\end{abstract}

Copy Right, IJAR, 2019,. All rights reserved.

\section{Introduction:}

Today computer revolution is affecting almost everyone's life. Technological advances and the accelerated transfer of information, along with related computer knowledge, skills, and abilities, have been of paramount importance in an information society. Computers have been pervasive in the work place, and in the home. The changes have shown how important the technologies have become to our daily life. Computer literacy may be defined, as whatever a person needs to know and do with electronic devices in order to function competently in our information-based society. However, to become familiar with electronic devices, one must first have access to them. But currently there is a large gap between the "haves" and the "have nots". Generally these skills can be learned in school, but a problem arises in the fact that during the student days of the government employees and local officials who have been in service for a longer time, computer subjects were not included in their curriculum.

According to Motowidlo, Borman, \&Schmit (1997), job performance is defined as the total expected value to the organization of the discrete behavioral episodes that an individual carries out over a standard period of time. This definition is a slightly revised version of the definition of performance we presented in a previous publication in connection with a theory of individual differences in task and contextual performance. Job performance refers to the effectiveness of individual behaviours that contribute to organizational objectives (McCloy, Campbell, \&Cudeck, 1994 in Motowidlo, 2003). Although there might be exceptions, high performers get promoted more easily within an organization and generally have better career opportunities than low performers (VanScotter, Motowidlo, \& Cross, 2000).

As observed, most of the government agencies now are using computers in various offices to help them improve their services to their clients in a lesser period of time and to enhance revenue as well. With the advent of information technology, the demand of clients also increases in terms of time and efficiency of needed services.

Corresponding Author: Rose May Cora P. Lagon, Ed.D.

Address: Associate Professor V, School of Information and Communications Technology, West Visayas State University Calinog Campus, Calinog, Iloilo, Philippines 5040. 
Instead of waiting for days they would like to finish their transactions in hours or in minutes. Government workers who belong to the older group have no computer background in their college days. Thus, though their office is equipped with the technology, still the employees are unwilling to use the available computers and other electronic devices due to lack of knowledge and skills in using this. This is considered as one of the barriers in using the computer and electronic devices. With these observed working situations, the researchers are motivated to conduct the study to determine in what way the WVSU-Calinog Campus could extend their expertise and resources to fellow government employees and local officials.

The study of computer literacy and job performance of the government employees and officials will determine the extent of need of the government employees and officials in Calinog for undergoing training in the use of computer and the technology needs of the offices in the government institution. It will be conducted with the government employees and officials in the Municipality of Calinog. It would help identify the training needs of the employees and officials that could aid them in the performance of their duties, by being productive in terms of the amount of work done, quality of output and timeliness.

\section{Methods:-}

This study aimed to determine the computer literacy and job performance of government employees and officials in the Municipality of Calinog.

This study specifically determined the competence in computer literacy if there is a significant relationship between competence in computer literacy job performance of government employees and officials in the municipality of Calinog.

The descriptive method of research was used in this study. Descriptive research describes and interprets what is. It is concerned with conditions of relationships that exists; practices that prevail; beliefs, processes that are going on; effects that are being felt, or trends that are developing. According to Subong (2005), descriptive research involves collecting data in order to test the hypotheses or answer questions concerning the current status of the subject of the study. Since this study is about the relationship between the level of computer literacy and job performance of Government Employees and Officials in the Municipality of Calinog, descriptive research was the most appropriate method of research to be used in this study.

The 121 respondents were the government officials and government employees working in the Municipal offices in Calinog and they are being selected using stratified random sampling.

To determine the computer literacy and job performance of respondents, the researcher employed three (2) standardized data-gathering instruments revised at certain degree to suit the needs of the present study. The instrument used were adopted from (Saud, 2005) Perception of Computer Technology Competencies; to gather data on job performance (AIA Knowledge Resources Staff, 2007) Performance Evaluation.

Lastly, for data analysis this study used mean, standard deviation for descriptive data analysis; Pearson's $\mathrm{r}$ for inferential data analysis.

The .05 alpha level was used as the criterion for the acceptance or rejection of the null hypotheses.

\section{Results:-}

As to Computer Operations Skills, the respondents are highly skilled on starting up and shutting down of the computer according to computer type $(M=4.09)$, highly skilled on using printing options $(M=3.83)$, and highly skilled on start an application and creating a document $(M=3.55)$.

Table 1 Computer Operations Skills

\begin{tabular}{|l|l|l|l|}
\hline \multicolumn{1}{|c|}{ Category } & Mean & Description & SD \\
\hline $\begin{array}{l}\text { Starting up and shutting down the computer according to } \\
\text { computer type. }\end{array}$ & 4.09 & Highly Skilled & 1.140 \\
\hline Using printing options. & 3.83 & Highly Skilled & 1.299 \\
\hline Start an application and creating a document. & 3.55 & Highly Skilled & 1.425 \\
\hline
\end{tabular}




\begin{tabular}{|c|c|c|c|}
\hline $\begin{array}{l}\text { Starting up and shutting down the peripherals (printer, } \\
\text { CD/DVD-ROM, and/or scanner). }\end{array}$ & 3.48 & Skilled & 1.245 \\
\hline $\begin{array}{l}\text { Saving a document using both the save and save as } \\
\text { commands. }\end{array}$ & 3.41 & Skilled & 1.429 \\
\hline $\begin{array}{l}\text { Copying document from hard disk to floppy disk, flash disk } \\
\text { and CD/DVD. }\end{array}$ & 3.39 & Skilled & 1.507 \\
\hline Identifying and use icons, windows, and menus. & 3.38 & Skilled & 1.343 \\
\hline 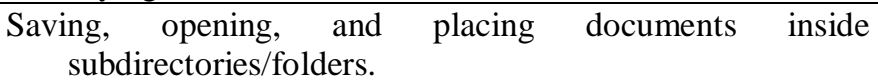 & 3.26 & Skilled & 1.401 \\
\hline Naming a document. & 3.17 & Skilled & 1.345 \\
\hline $\begin{array}{l}\text { Inserting and ejecting CD/DVD, flash disk, external floppy } \\
\text { disk and hard disk }\end{array}$ & 3.02 & Skilled & 1.557 \\
\hline $\begin{array}{l}\text { Opening and working with more than one application at a } \\
\text { time. }\end{array}$ & 2.78 & Skilled & 1.737 \\
\hline Creating and naming and renaming subdirectories/folders & 2.77 & Skilled & 1.626 \\
\hline $\begin{array}{l}\text { Initializing, naming/renaming CD/DVD, flash disk, floppy } \\
\text { disk and hard disk. }\end{array}$ & 2.71 & Skilled & 1.518 \\
\hline
\end{tabular}

$\begin{array}{cl}\text { Scale } & \text { Description } \\ 4.51-5.00 & \text { Very Highly Skilled } \\ 3.51-4.50 & \text { Highly Skilled } \\ 2.51-3.50 & \text { Skilled } \\ 1.51-2.50 & \text { Moderately Skilled } \\ 1.00-1.50 & \text { Not Skilled }\end{array}$

As to set up, maintenance and troubleshooting the respondents have the following top these skills: first protecting and caring for flash or extent disks $(M=3.34)$; second is connecting peripheral devices. (i.e. printers ,CD/DVDROM, external drives, modem, scanner) $(M=3.19)$; and third, cleaning computer components and printers $(M=3.06)$.

Table 2 Set-up, Maintenance and Troubleshooting

\begin{tabular}{|l|l|l|l|}
\hline \multicolumn{1}{|c|}{ Category } & Mean & Description & SD \\
\hline Protecting and caring for flash or external disks. & 3.34 & Skilled & 1.508 \\
\hline $\begin{array}{l}\text { Connecting peripheral devices (i.e. printers, CD/DVD-ROM, external drives, } \\
\text { modem, scanner) }\end{array}$ & 3.19 & Skilled & 1.598 \\
\hline Cleaning computer components \& printers. & 3.06 & Skilled & 1.491 \\
\hline Proper operating environment for computer and peripherals. & 3.01 & Skilled & 1.475 \\
\hline Protecting against computer viruses. & 3.00 & Skilled & 1.532 \\
\hline Making backup copies of key applications and documents. & 2.94 & Skilled & 1.567 \\
\hline Setting up computer system (i.e.: CPU*; monitor; keyboard; and mouse) & 2.74 & Skilled & 1.418 \\
\hline Using self-help resources to diagnose and correct common hardware problems. & 2.71 & Skilled & 1.393 \\
\hline Installing and upgrading an application. & 2.69 & Skilled & 1.377 \\
\hline
\end{tabular}

$\begin{array}{ll}\text { Scale } & \text { Description } \\ 4.51-5.00 & \text { Very Highly Skilled } \\ 3.51-4.50 & \text { Highly Skilled } \\ 2.51-3.50 & \text { Skilled } \\ 1.51-2.50 & \text { Moderately Skilled } \\ 1.00-1.50 & \text { Not Skilled }\end{array}$

When it comes to word processing/introductory desktop publishing the respondents are highly skilled in checking spelling, grammar and word usage $(M=3.66)$, highly skilled entering and editing text $(M=3.59)$ and skilled in using tab stop (aligning, justifying, to left, right, center, decimal tab) $(M=3.37)$. 
Table 3 Word Processing/Introductory Desktop Publishing

\begin{tabular}{|l|l|l|l|}
\hline \multicolumn{1}{|c|}{ Category } & Mean & Description & SD \\
\hline Checking spelling, grammar, and word usage. & 3.66 & Highly Skilled & 1.514 \\
\hline Entering and editing text. & 3.59 & Highly Skilled & 1.256 \\
\hline Using tab stop (align/justify to left, right, center, decimal tab). & 3.37 & Skilled & 1.549 \\
\hline $\begin{array}{l}\text { Using margins (amount of white space on the top, bottom, left } \\
\text { and right edges of page). }\end{array}$ & 3.21 & Skilled & 1.678 \\
\hline Inserting date, time, and page number. & 3.23 & Skilled & 1.289 \\
\hline Adding columns to a document. & 3.19 & Skilled & 1.639 \\
\hline Creating a header and footer. & 3.07 & Skilled & 1.395 \\
\hline $\begin{array}{l}\text { Changing text format and style change actual size of text and } \\
\text { choose type and special effects such as bold, italic, or } \\
\text { underline). }\end{array}$ & 3.00 & Skilled & 1.414 \\
\hline Inserting clip art into a document. & 2.50 & Moderately Skilled & 1.467 \\
\hline
\end{tabular}

$\begin{array}{ll}\text { Scale } & \text { Description } \\ 4.51-5.00 & \text { Very Highly Skilled } \\ 3.51-4.50 & \text { Highly Skilled } \\ 2.51-3.50 & \text { Skilled } \\ 1.51-2.50 & \text { Moderately Skilled } \\ 1.00-1.50 & \text { Not Skilled }\end{array}$

As far as Spreadsheet and Graphing are concerned, the respondents are skilled in interpreting the information from a spreadsheet and communicating the data in a graphical format $(M=2.95)$, skilled in creating spreadsheet with rows, columns and headings $M=(2.89)$ and skilled in creating a formula using functions $(M=2.88)$.

Table 4Spreadsheet/Graphing

\begin{tabular}{|l|l|l|l|}
\hline \multicolumn{1}{|c|}{ Category } & Mean & Description & SD \\
\hline $\begin{array}{l}\text { Interpreting the information from a spreadsheet and communicating the data in } \\
\text { a graphical format. }\end{array}$ & 2.95 & Skilled & 1.465 \\
\hline $\begin{array}{l}\text { Creating a spreadsheet with rows, columns, and headings. } \\
\text { Creating a formula using functions. }\end{array}$ & 2.89 & Skilled & 1.431 \\
\hline Understanding the three basic types of cells; label; value, and formula. & 2.88 & Skilled & 1.507 \\
\hline Understanding the possibilities of spreadsheet calculations. & 2.74 & Skilled & Skilled \\
\hline Changing the appearance of a spreadsheet by inserting columns and rows. & 2.73 & Skilled & 1.407 \\
\hline Inserting a spreadsheet into a word processing document. & 2.72 & Skilled & 1.461 \\
\hline Copying values using fill down and fill across. & 2.69 & Skilled & 1.386 \\
\hline $\begin{array}{l}\text { Entering data in an existing spreadsheet. } \\
\text { Understanding the concept of spreadsheet and relating a print spreadsheet to an } \\
\text { electronic spreadsheet. }\end{array}$ & 2.59 & $\begin{array}{l}\text { Moderately } \\
\text { Skilled }\end{array}$ & 1.509 \\
\hline $\begin{array}{l}\text { Creating a graph or chart from spreadsheet data. } \\
\text { Skilled }\end{array}$ & 2.47 & $\begin{array}{l}\text { Moderately } \\
\text { Skilled }\end{array}$ & 1.453 \\
\hline
\end{tabular}

$\begin{array}{ll}\text { Scale } & \text { Description } \\ 4.51-5.00 & \text { Very Highly Skilled } \\ 3.51-4.50 & \text { Highly Skilled } \\ 2.51-3.50 & \text { Skilled } \\ 1.51-2.50 & \text { Moderately Skilled } \\ 1.00-1.50 & \text { Not Skilled }\end{array}$

In database, the respondents are skilled using of sorting and searching techniques to solved a problem $(M=2.77)$, skilled in searching a data base for specific information $(M=2.76)$ and skilled in using a database to search for desired information given $(M=2.66)$. 
Table 5 Database

\begin{tabular}{|l|l|l|l|}
\hline \multicolumn{1}{|c|}{ Category } & Mean & Description & SD \\
\hline Using sorting and searching techniques to solve a problem. & 2.77 & Skilled & 1.662 \\
\hline Searching a database for specific information. & 2.76 & Skilled & 1.426 \\
\hline Using a database to search for desired information given. & 2.66 & Skilled & 1.480 \\
\hline Adding and delete a record to an existing database. & 2.64 & Skilled & 1.471 \\
\hline Using a prepared database to enter data & 2.62 & Skilled & 1.545 \\
\hline Using a database to sort records. & 2.55 & Skilled & 1.488 \\
\hline Creating a database with multiple fields. & 2.46 & Moderately Skilled & 1.426 \\
\hline Inserting database fields into word processing document. & 2.39 & Moderately Skilled & 1.485 \\
\hline
\end{tabular}

$\begin{array}{ll}\text { Scale } & \text { Description } \\ 4.51-5.00 & \text { Very Highly Skilled } \\ 3.51-4.50 & \text { Highly Skilled } \\ 2.51-3.50 & \text { Skilled } \\ 1.51-2.50 & \text { Moderately Skilled } \\ 1.00-1.50 & \text { Not Skilled }\end{array}$

In networking, the respondents are skilled in disconnecting/logging off $(M=3.36)$, saving a document to a specified location of school $(M=3.21)$ and selecting/de-selecting a network zone $(M=2.74)$.

\section{Table 6 Networking}

\begin{tabular}{|l|l|l|l|}
\hline \multicolumn{1}{|c|}{ Category } & Mean & Description & SD \\
\hline Disconnecting/logging off. & 3.36 & Skilled & 1.183 \\
\hline Saving a document to a specified location of school. & 3.21 & Skilled & 1.414 \\
\hline Selecting/de-selecting a network zone. & 2.74 & Skilled & 1.487 \\
\hline Sharing files with others on a network. & 2.72 & Skilled & 1.477 \\
\hline Connecting/logging on to a file server. & 2.63 & Skilled & 1.592 \\
\hline Retrieving a program or document. & 2.42 & Skilled & 1.453 \\
\hline
\end{tabular}

$\begin{array}{ll}\text { Scale } & \text { Description } \\ 4.51-5.00 & \text { Very Highly Skilled } \\ 3.51-4.50 & \text { Highly Skilled } \\ 2.51-3.50 & \text { Skilled } \\ 1.51-2.50 & \text { Moderately Skilled } \\ 1.00-1.50 & \text { Not Skilled }\end{array}$

In an area of telecommunications, the respondents are skilled in using browser software $(M=3.13)$, skilled in connecting to internet service $(M=3.12)$ and skilled in finding search engine and perform specific web search $(M=3.02)$.

Table 7 Telecommunications

\begin{tabular}{|l|l|l|l|}
\hline \multicolumn{1}{|c|}{ Category } & Mean & Description & SD \\
\hline Using browser software (concepts: hypertext, html, homepage). & 3.13 & Skilled & 1.527 \\
\hline $\begin{array}{l}\text { Connecting to Internet via an Internet Service Provider (ISP) with } \\
\text { a user ID and password. }\end{array}$ & 3.12 & Skilled \\
\hline $\begin{array}{l}\text { Finding search engine site and perform a specific web search (list } \\
\text { of search engines. }\end{array}$ & 3.02 & Skilled & 1.484 \\
\hline $\begin{array}{l}\text { Being aware of on-line conference relevant to professional } \\
\text { information. }\end{array}$ & 2.86 & Skilled & 1.374 \\
\hline $\begin{array}{l}\text { Sending e-mail (concepts of carbon copy (cc) and blind carbon } \\
\text { copy (bcc)). }\end{array}$ & 2.85 & Skilled \\
\hline Uploading a text file and sending as electronic mail. & 2.85 & Skilled & Skilled \\
\hline $\begin{array}{l}\text { Knowing and using of filter (software driven, server based, search } \\
\text { engine inclusive). }\end{array}$ & 2.71 & 1.412 \\
\hline Obtaining/maintaining an account on the Internet or an on-line & 2.70 & Skilled & 1.522 \\
\hline
\end{tabular}




\begin{tabular}{|l|l|l|l|}
\hline service that provides Internet access. & & & \\
\hline $\begin{array}{l}\text { Composing new e-mail (address and subject; explanation of } \\
\text { address domains) }\end{array}$ & 2.66 & Skilled & 1.502 \\
\hline $\begin{array}{l}\text { Connecting a computer to a modem and telephone line for dial-in } \\
\text { access. }\end{array}$ & 2.64 & Skilled & 1.347 \\
\hline Using FTP* to sendor retrieve files from remote computers. & 2.63 & Skilled & 1.478 \\
\hline Reading, saving, printing, replying to forward electronic mail. & 2.55 & Skilled & 1.341 \\
\hline Creating and using group addresses for electronic mail. & 2.52 & Skilled & 1.232 \\
\hline $\begin{array}{l}\text { Effective using of distance learning desktop video conferencing, } \\
\text { and tele-teaching technologies. }\end{array}$ & 2.49 & Moderately Skilled & 1.438 \\
\hline Connecting to country or university library. & 2.36 & Moderately Skilled & 1.378 \\
\hline Using Gopher to browse resources on the Internet. & 2.33 & Moderately Skilled & 1.344 \\
\hline Installing and configuring telecommunications software. & 2.32 & Moderately Skilled & 1.343 \\
\hline
\end{tabular}

$\begin{array}{ll}\text { Scale } & \text { Description } \\ 4.51-5.00 & \text { Very Highly Skilled } \\ 3.51-4.50 & \text { Highly Skilled } \\ 2.51-3.50 & \text { Skilled } \\ 1.51-2.50 & \text { Moderately Skilled } \\ 1.00-1.50 & \text { Not Skilled }\end{array}$

In media communication, the respondents are moderately skilled in connecting a video output devices (LCD panel or LCD projector*) to computer for large screen display $(M=2.53)$, setting up and operating a videocassette recorder/player and monitor/TV $(M=2.45)$ and using digital camera and scanner $(M=2.42)$.

Table 8 Media Communications

\begin{tabular}{|l|l|l|l|}
\hline \multicolumn{1}{|c|}{ Category } & Mean & Description & SD \\
\hline $\begin{array}{c}\text { Connecting a video output devices (LCD panel or LCD } \\
\text { projector*) to computer for large screen display. }\end{array}$ & 2.53 & Skilled & 1.232 \\
\hline $\begin{array}{c}\text { Setting up and operating a videocassette recorder/player and } \\
\text { monitor/TV. }\end{array}$ & 2.45 & Moderately Skilled & 1.366 \\
\hline Using digital camera and scanner. & 2.42 & Moderately Skilled & 1.471 \\
\hline $\begin{array}{l}\text { Producing print-based products (e.g., newsletters, brochures, } \\
\text { poster, books). }\end{array}$ & 2.41 & Moderately Skilled & 1.376 \\
\hline Knowing how to use painting and drawing tools. & 2.36 & Moderately Skilled & 1.555 \\
\hline Producing electronic slides/overheads & 2.27 & Moderately Skilled & 1.304 \\
\hline $\begin{array}{c}\text { Setting up and operate a videodisk player and TV receiver or } \\
\text { monitor. }\end{array}$ & 2.23 & Moderately Skilled & 1.338 \\
\hline Using camcorder and edit video from a camcorder. & 2.22 & Moderately Skilled & 1.363 \\
\hline Producing a video. & 2.14 & Moderately Skilled & 1.231 \\
\hline $\begin{array}{c}\text { Using digital document camera for 3D objects as well as } \\
\text { documents and slides presentation. }\end{array}$ & 2.13 & Moderately Skilled & 1.408 \\
\hline
\end{tabular}

$\begin{array}{cl}\text { Scale } & \text { Description } \\ 4.51-5.00 & \text { Very Highly Skilled } \\ 3.51-4.50 & \text { Highly Skilled } \\ 2.51-3.50 & \text { Skilled } \\ 1.51-2.50 & \text { Moderately Skilled } \\ 1.00-1.50 & \text { Not Skilled }\end{array}$

\section{Job Performance}

For the job performance it was categorized according to communications, cost consciousness, delegation, job knowledge, judgement, leadership, managing people, planning and organization, problem solving, and quality.

In communications, the respondents are all average in using appropriate communications methods $(M=3.60)$, expressing ideas and thoughts verbally $(M=3.37)$ and expressing ideas thoughts in written form $(M=3.34)$. 
Table 10 Communications

\begin{tabular}{|l|l|l|l|}
\hline \multicolumn{1}{|c|}{ Category } & Mean & Description & SD \\
\hline Using appropriate communication methods & 3.60 & High & 1.165 \\
\hline Expressing ideas and thoughts verbally & 3.37 & Average & 1.218 \\
\hline Expressing ideas and thoughts in written form & 3.34 & Average & 1.194 \\
\hline Exhibiting good listening and comprehension & 3.33 & Average & 1.254 \\
\hline Keeping others adequately informed & 3.21 & Average & 1.271 \\
\hline
\end{tabular}

$\begin{array}{ll}\text { Scale } & \text { Description } \\ 4.51-5.00 & \text { Very High } \\ 3.51-4.50 & \text { High } \\ 2.51-3.50 & \text { Average } \\ 1.51-2.50 & \text { Low } \\ 1.00-1.50 & \text { Very Low }\end{array}$

As the cost consciousness, the respondents are high is working within approved budget $(M=3.51)$, and conserving organizational resources $(M=3.51)$ and developing and implementing cost-saving measures $(M=3.31)$.

Table 11 Cost Consciousness

\begin{tabular}{|l|l|l|l|}
\hline \multicolumn{1}{|c|}{ Category } & Mean & Description & SD \\
\hline Working within approved budget & 3.51 & High & 1.131 \\
\hline Conserving organizational resources & 3.51 & High & 1.162 \\
\hline Developing and implementing cost-saving measures & 3.31 & Average & 1.223 \\
\hline Contributing to profits and revenue & 3.21 & Average & 1.224 \\
\hline
\end{tabular}

$\begin{array}{ll}\text { Scale } & \text { Description } \\ 4.51-5.00 & \text { Very High } \\ 3.51-4.50 & \text { High } \\ 2.51-3.50 & \text { Average } \\ 1.51-2.50 & \text { Low } \\ 1.00-1.50 & \text { Very Low }\end{array}$

As delegation, the respondents high is giving authority to work independently $(M=3.57)$, matching the responsibility to the person $(M=3.47)$, and providing recognition for results $(M=3.43)$.

Table 12 Delegation

\begin{tabular}{|l|l|l|l|}
\hline \multicolumn{1}{|c|}{ Category } & Mean & Description & SD \\
\hline Giving authority to work independently & 3.57 & High & 1.174 \\
\hline Matching the responsibility to the person & 3.47 & High & 1.190 \\
\hline Providing recognition for results & 3.43 & High & 1.347 \\
\hline Delegating work assignments & 3.42 & High & 1.282 \\
\hline Setting expectations and monitors delegated activities & 3.28 & Average & 1.060 \\
\hline
\end{tabular}

$\begin{array}{cl}\text { Scale } & \text { Description } \\ 4.51-5.00 & \text { Very High } \\ 3.51-4.50 & \text { High } \\ 2.51-3.50 & \text { Average } \\ 1.51-2.50 & \text { Low } \\ 1.00-1.50 & \text { Very Low }\end{array}$

In job knowledge, the respondents are high in competence in required job skills and knowledge $(M=3.75)$, using resources effectively $(M=3.72)$ and exhibiting ability to learn and apply new skills $(M=3.63)$. 
Table 13 Job Knowledge

\begin{tabular}{|l|l|l|l|}
\hline \multicolumn{1}{|c|}{ Category } & Mean & Description & SD \\
\hline Competent in required job skills and knowledge & 3.75 & High & 1.043 \\
\hline Uses resources effectively & 3.72 & High & 1.284 \\
\hline Exhibits ability to learn and apply new skills & 3.63 & High & 1.169 \\
\hline Keeps abreast of current developments & 3.45 & Average & 1.190 \\
\hline Displays understanding of how job relates to others & 3.36 & Average & 1.190 \\
\hline Requires minimal supervision & 3.30 & Average & 1.196 \\
\hline
\end{tabular}

$\begin{array}{ll}\text { Scale } & \text { Description } \\ 4.51-5.00 & \text { Very High } \\ 3.51-4.50 & \text { High } \\ 2.51-3.50 & \text { Average } \\ 1.51-2.50 & \text { Low } \\ 1.00-1.50 & \text { Very Low }\end{array}$

As to judgement, the respondents are in high in supporting and explaining reasoning for decisions $(M=3.61)$, including appropriate people in decisions $(M=3.61)$ and exhibiting sound and accurate judgement $(M=3.53)$.

Table 14 Judgment

\begin{tabular}{|l|l|l|l|}
\hline \multicolumn{1}{|c|}{ Category } & Mean & Description & SD \\
\hline Supporting and explains reasoning for decisions & 3.61 & High & 1.035 \\
\hline Including appropriate people in decision-making process. & 3.60 & High & 1.028 \\
\hline Exhibiting sound and accurate judgment & 3.53 & High & 1.025 \\
\hline Displaying willingness to make decisions & 3.50 & Average & 1.184 \\
\hline Making timely decisions & 3.30 & Average & 1.203 \\
\hline
\end{tabular}

$\begin{array}{cl}\text { Scale } & \text { Description } \\ 4.51-5.00 & \text { Very High } \\ 3.51-4.50 & \text { High } \\ 2.51-3.50 & \text { Average } \\ 1.51-2.50 & \text { Low } \\ 1.00-1.50 & \text { Very Low }\end{array}$

In Leadership, the respondents are highly in motivating others to perform well $(M=3.79)$, showing courage to take action $(M=3.58)$ and exhibiting confidence in self and others $(M=3.56)$.

Table 15 Leadership

\begin{tabular}{|l|l|l|l|}
\hline \multicolumn{1}{|c|}{ Category } & Mean & Description & SD \\
\hline Motivating others to perform well & 3.79 & High & 1.161 \\
\hline Showing courage to take action & 3.58 & High & 1.222 \\
\hline Exhibiting confidence in self and others & 3.56 & High & 1.071 \\
\hline Inspiring respect and trust & 3.47 & High & 1.310 \\
\hline Reacting well under pressure & 3.43 & High & 1.139 \\
\hline
\end{tabular}

$\begin{array}{cl}\text { Scale } & \text { Description } \\ 4.51-5.00 & \text { Very High } \\ 3.51-4.50 & \text { High } \\ 2.51-3.50 & \text { Average } \\ 1.51-2.50 & \text { Low } \\ 1.00-1.50 & \text { Very Low }\end{array}$

In managing people, the respondents are high in takes responsibility for subordinates activities $(M=3.73)$, developing subordinates skills and encourages growth $(M=3.72)$ and providing direction and gains compliance $(M=3.71)$. 
Table 16 Managing People

\begin{tabular}{|l|l|l|l|}
\hline \multicolumn{1}{|c|}{ Category } & Mean & Description & SD \\
\hline Taking responsibility for subordinates' activities & 3.73 & High & 1.078 \\
\hline Developing subordinates' skills and encourages growth & 3.72 & High & 1.095 \\
\hline Providing direction and gains compliance & 3.71 & High & 1.003 \\
\hline Including subordinates in planning & 3.61 & High & 1.266 \\
\hline Making self available to subordinates & 3.47 & High & 1.017 \\
\hline Providing regular performance feedback & 3.46 & High & 1.218 \\
\hline
\end{tabular}

$\begin{array}{cl}\text { Scale } & \text { Description } \\ 4.51-5.00 & \text { Very High } \\ 3.51-4.50 & \text { High } \\ 2.51-3.50 & \text { Average } \\ 1.51-2.50 & \text { Low } \\ 1.00-1.50 & \text { Very Low }\end{array}$

In planning and organizing, the respondents are high in prioritizing and planning works activities $(M=3.80)$, working in an organized manner $(M=3.73)$ and setting goal and objectives $(M=3.70)$.

Table 17 Planning and Organization

\begin{tabular}{|l|l|l|l|}
\hline \multicolumn{1}{|c|}{ Category } & Mean & Description & SD \\
\hline Prioritizing and planning work activities & 3.80 & High & 1.084 \\
\hline Working in an organized manner & 3.73 & High & 1.188 \\
\hline Setting goals and objectives & 3.70 & High & 1.282 \\
\hline Planning for additional resources & 3.62 & High & 1.192 \\
\hline Using time efficiently & 3.52 & High & 1.190 \\
\hline Integrating changes smoothly & 3.40 & High & 1.221 \\
\hline
\end{tabular}

$\begin{array}{ll}\text { Scale } & \text { Description } \\ 4.51-5.00 & \text { Very High } \\ 3.51-4.50 & \text { High } \\ 2.51-3.50 & \text { Average } \\ 1.51-2.50 & \text { Low } \\ 1.00-1.50 & \text { Very Low }\end{array}$

In problem solving, the respondents are high in developing alternative solutions $(M=3.62)$, identifying problem in a timely manner $(M=3.56)$ and gathering and analyzing information skilfully $(M=3.53)$.

Table 18 Problem Solving

\begin{tabular}{|l|l|l|l|}
\hline \multicolumn{1}{|c|}{ Category } & Mean & Description & SD \\
\hline Developing alternative solutions & 3.62 & High & 1.272 \\
\hline Identifying problems in a timely manner & 3.56 & High & 1.063 \\
\hline Gathering and analysing information skilfully & 3.53 & High & 1.251 \\
\hline Resolving problems in early stages & 3.46 & High & 1.204 \\
\hline Working well in group problem-solving situations & 3.37 & Average & 1.278 \\
\hline
\end{tabular}

$\begin{array}{cl}\text { Scale } & \text { Description } \\ 4.51-5.00 & \text { Very High } \\ 3.51-4.50 & \text { High } \\ 2.51-3.50 & \text { Average } \\ 1.51-2.50 & \text { Low } \\ 1.00-1.50 & \text { Very Low }\end{array}$

As far as quality is concerned, the respondents are in displaying commitment excellence $(M=3.62)$, looking for ways to improve and promote quality $(M=3.51)$ and monitors own work to ensure quality $(M=3.44)$. 
Table 19 Quality

\begin{tabular}{|l|l|l|l|}
\hline \multicolumn{1}{|c|}{ Category } & Mean & Description & SD \\
\hline Displaying commitment to excellence & 3.62 & High & 1.219 \\
\hline Looking for ways to improve and promote quality & 3.51 & High & 1.438 \\
\hline Monitoring own work to ensure quality & 3.44 & High & 1.309 \\
\hline Demonstrating accuracy and thoroughness & 3.43 & High & 1.153 \\
\hline Applying feedback to improve performance & 3.39 & High & 1.344 \\
\hline
\end{tabular}

$\begin{array}{ll}\text { Scale } & \text { Description } \\ 4.51-5.00 & \text { Very High } \\ 3.51-4.50 & \text { High } \\ 2.51-3.50 & \text { Average } \\ 1.51-2.50 & \text { Low } \\ 1.00-1.50 & \text { Very Low }\end{array}$

For the relationship between computer literacy and job performance of government employees and officials in the municipality of Calinog. Using the Pearson's $r$ as inferential statistics, the relationship between computer literacy and job performance was looked into. For competence in computer literacy and job performance they have significant correlation existed as shown by Pearson's $\mathrm{r}$ of .514 and two-tailed probability of .000 which was lesser than the set of 0.05 level of significance. Therefore, Competence and Job Performance have significant relationship.

Table 20 Relationship betweenComputer Literacy, Job Satisfaction and Job Performance

\begin{tabular}{|l|l|l|l|}
\hline Correlated Variable & $\mathbf{N}=\mathbf{1 2 1}$ & Competence & Job Performance \\
\hline Computer Literacy & Pearson Correlation & 1 & $.514(* *)$ \\
\hline & Significance(2-tailed) &. & .000 \\
\hline Job Performance & $\mathrm{N}$ & 121 & 121 \\
\hline & Pearson Correlation & $.514(* *)$ & 1 \\
\hline & Significance(2-tailed) & .000 &. \\
\hline & $\mathrm{N}$ & 121 & 121 \\
\hline
\end{tabular}

** Correlation at $0.01(2$-tailed):...

\section{Conclusion and Recommendation:-}

The study showed that the government employees and officials in the Municipality of Calinog very highly skilled in computer operation skills such as starting up and shutting down the computer according to type, highly skilled in starting up and shutting down the peripherals, identifying and use icons, windows, and menus and saving a document using both the save as commands and skilled in seven other categories. This confirmed the level of basic computer literacy among government employees and officials was not adequate. Therefore, the computer operation skills were the minor educational needs among the employees and officials.

The highest computer literacy educational needs were in media communication as the study showed moderately skilled in all categories. The reason could be that the skills involve more expensive equipment and may coincide with desires of the employees and officials to be more creative. Another reason might be the municipal government do not have the equipment. As a result, the employees and officials in the Municipality of Calinog had not an opportunity to learn those skills.

The second highest computer literacy educational needs was telecommunication, especially moderately skilled in the category of in effective use of distance learning desktop video conferencing, and tele-teaching technologies and use FTP to send or retrieve files, using Gopher to browse resources on the internet, reading, saving, printing, replying to forward electronic mail, creating and using group addresses for electronic mail, installing and configuring telecommunications software and connecting to country or university library. This finding confirmed that more complicated and high-tech knowledge and skills produced low employees and officials' competence in that area. The reason could be because, in Municipality of Calinog offices, these innovations were still new and only certain people knew how to operate the equipment. The development of internet technology also might be the reason why 
telecommunication computer literacy skills had the highest educational needs among government employees and officials.

Based on the rank of highest to lowest educational computer literacy needs of the eight domains, the study found that media communication was the top followed by telecommunication, networking, database, spreadsheet/graphing, setup, maintenance and trouble shooting, word processing/introductory desktop publishing and computer operating system. This information could be used to develop a computer literacy training program by the researchers in the School of Information and Communications Technology.

The government employees and officials in the Municipality of Calinog average and high in different aspects of job performance. It means that in these aspects, there are still areas for improvement. It is therefore, recommended that the skills may be improve in computer literacy that may improve and job performance of the respondents through interventions such as skills training, seminars and workshops.

\section{References:-}

1. AIA Knowledge Resources Staff. (2007) Performance Evaluation Forms. bestpractices@aia.org

2. Brayfield, A.H., \&Rothe, H.F. (1951). An index of job satisfaction. Journal of Applied Psychology, 35, 307311.

3. Croxall, K., \& Cummings, M. N. (2000). Computer usage in family and consumer sciences classrooms [Electronic Version]. Journal of Family and Consumer Sciences Education 18(1), 9-18)

4. Dillan, A. and Morris, M. (1996) User Acceptance of New Technology: Theories and Models. In M. Williams (ed.) Amend Review of Information Science and Technology, Vol. 31, Redford NJ: Information Today, 3-32.

5. Jones-Kavalier,B.R. and Flannigan, S.L.(2006), Connecting the digital dots: Literacy of the $21^{\text {st }}$ century. EDUCAUSE Quarterly, Vol. 29, No.2, 2006, pp. 8-10.

6. Saud, M. (2005). Computer Technology Competencies Perceived as Needed by Vocational and Technical Teachers in Malaysia. Published Doctoral Dissertation, Ohio State University, Columbus, Ohio.

7. Schleicher, D.J., Watt J.D., Greguras G.J. (2004), Reexamining the Job Satisfaction-Performance Relationship: The Complexity of Attitudes, Journal of Applied Psychology Copyright 2004 by the American Psychological Association, Inc. 2004, Vol. 89, No. 1

8. Subong, P. (2005). Statistics for research. Applications in research, thesis and dissertation writing, and statistical data management using SPSS software. $1^{\text {st }}$ Edition: Rex Book Store, Inc. 